\author{
MAKALAH \\ PANCASILA SEBAGAI IDEOLOGI \\ Disusun untuk memenuhi tugas \\ MATA KULIAH : PENDIDIKAN PANCASILA \\ DOSEN PENGAMPU : KRISTA SURBAKTI S.Pd., M.Si
}

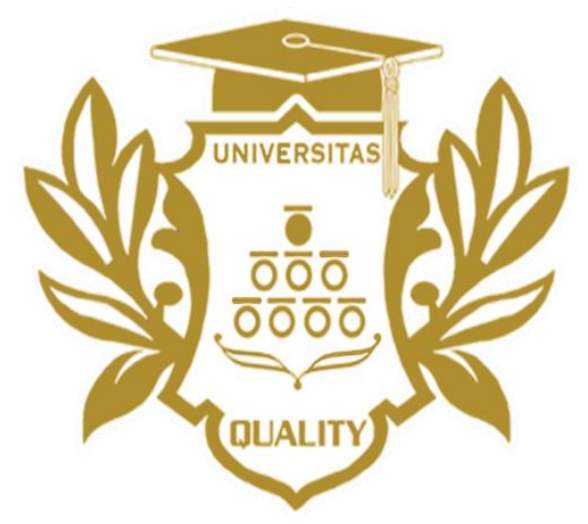

OLEH :

1. JAKOBUS SEMBIRING

2. MIA SAHENNA

3. PUTRI AYU ANATASYA

4. ADE VIONIKA

5. REHULINA APULISA

6. AGNES JESICA

KELAS 2A12

JURUSAN PENDIDIKAN GURU SEKOLAH DASAR(PGSD)

FAKULTAS KEGURUAN DAN ILMU PENDIDIKAN(FKIP) 


\section{KATA PENGANTAR}

Puji syukur kami panjatkan Kepada Tuhan Yang Maha Esa atas anugrah-Nya sehingga kami dapat menyelesaikan penulisan makalah tentang Pancasila Sebagai Ideologi.

Adapun maksud dan tujuan dari penyusunan Makalah ini selain untuk menyelesaikan tugas yang diberikan oleh Dosen pengajar, juga untuk lebih memperluas pengetahuan para mahasiswa khususnya bagi penulis.

Penulis telah berusaha untuk dapat menyusun Makalah ini dengan baik, namun penulis pun menyadari bahwa kami memiliki akan adanya keterbatasan kami sebagai manusia biasa. Oleh karena itu jika didapati adanya kesalahan-kesalahan baik dari segi teknik penulisan, maupun dari isi, maka kami memohon maaf dan kritik

serta saran dari dosen pengajar bahkan semua pembaca sangat diharapkan oleh kami untuk dapat menyempurnakan makalah ini terlebih juga dalam pengetahuan kita bersama. 


\section{Daftar isi}

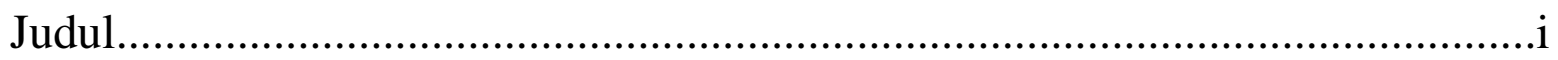

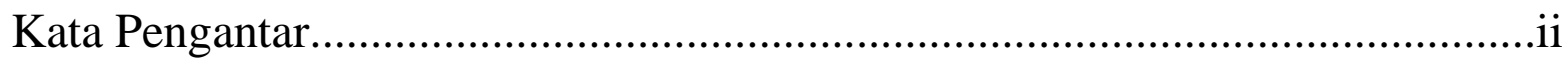

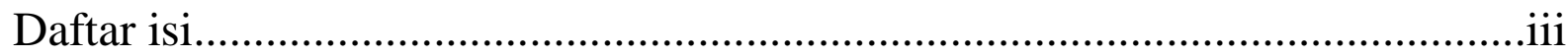

\section{Bab 1 Pendahuluan}

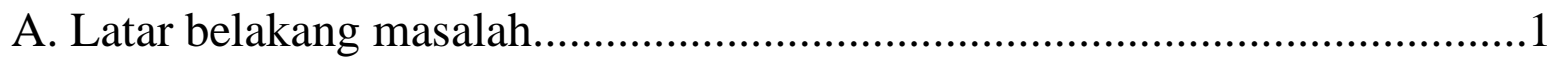

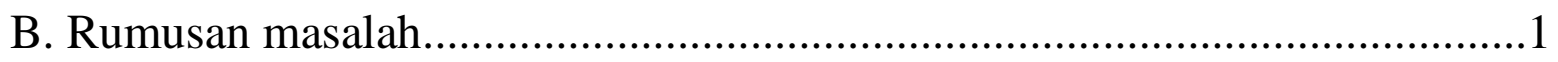

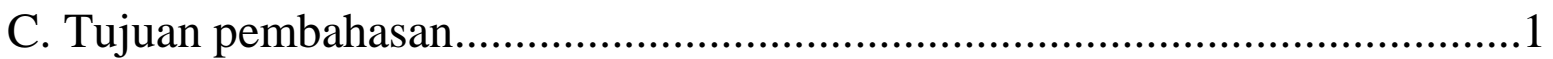

Bab 2 Pembahasan

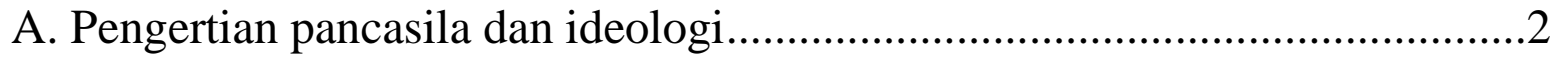

B. Pengertian pancasila sebagai ideologi ......................................2

C. Hubungan pancasila dengan ideologi ....................................................... 3

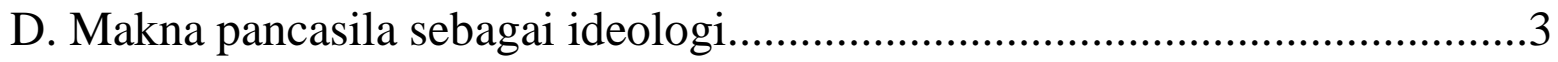

E. Pandangan para ahli mengenai makna dari pancasila sebagai ideologi..........4

F. Fungsi pancasila sebagai ideologi ........................................................

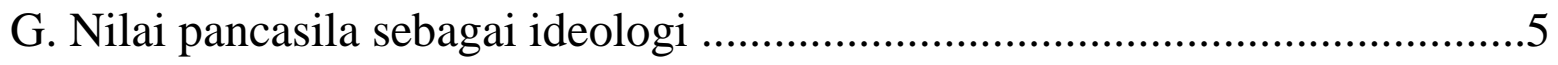

H. Perbandingan ideologi pancasila dengan ideologi yang lainnya....................5

I. Faktor-faktor yang mendasari pancasila dipilih sebagai ideologi...................12

\section{Bab 3 Penutup}

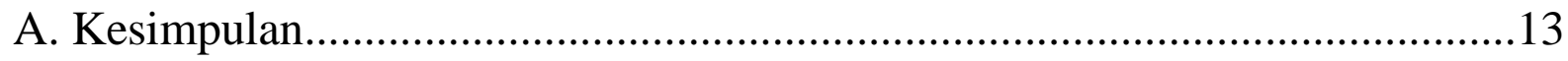

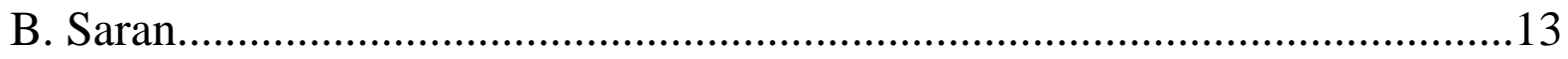

C. Hasil laporan wawancara(Dokumentasi)..............................14

\section{Daftar Pustaka}




\section{BAB I \\ PENDAHULUAN}

\section{A. Latar belakang}

Seluruh negara-negara didunia ini pasti memiliki suatu landasan atau dasar yang kita kenal dengan Ideologi. Karena ideolgi merupakan merupakan dasar atau ide atau citacita negara tersebut untuk semakin berkembang dan maju.Presiden dalam memimpin bangsa Indonesia dia tidak bisa mengandal visi dan misinya sendiri untuk mencapai cita-cita bangsa, oleh karena itu harus memiliki suatu dasar atau landasan yang dapat dijadikan sebagai patokan. Ideologi negara Indonesia adalah Pancasila, pancasila bukan Ideologi negara bagi sebagian atau daerah-daerah tertentu saja tetapi menyuluruh, terkadang perbedaan pendapat dalam mengartikan dasar negara maka terjadilah pertikaian.

\section{B. Rumuasan Masalah}

1. Apa pengertian Pancasila sebagai ideologi?

2. Jelaskan makna Pancasila sebagai ideologi!

3. Jelaskan fungsi Pancasila sebagai ideologi!

4. Jelaskan nilai Pancasila sebagai ideologi!

5. Jelaskan perbandingan ideologi pancasila dengan ideologi yang lainnya!

6.Sebutkan faktor-faktor yang mendasari pancasila dipilih sebagai ideologi!

\section{C.Tujuan Masalah}

1. Mendeskripsikan pengertian pancasila sebagai ideologi

2. Mendeskripsikan makna pancasila sebagai ideologi

3. Mendeskripsikan fungsi pancasila sebagai ideologi

4. Mendeskripsikan nilai pancasila sebagai ideologi

5. Mendeskripsikan perbandingan ideologi pancasila dengan ideologi yang lainnya

6. Mendeskripsikan faktor-faktor yang mendasari pancasila dipilih sebagai ideologi 


\section{BAB II}

\section{PEMBAHASAN}

\section{A.Pengertian Pancasila dan Ideologi}

Pancasila adalah ideologi dasar dalam kehidupan bagi negara Indonesia. Nama ini terdiri dari dua kata dari Sanskerta: pañca berarti lima dan śīla berarti prinsip atau asas. Pancasila merupakan rumusan dan pedoman kehidupan berbangsa dan bernegara bagi seluruh rakyat Indonesia.Lima sendi utama penyusun Pancasila adalah Ketuhanan Yang Maha Esa, kemanusiaan yang adil dan beradab, persatuan Indonesia, kerakyatan yang dipimpin oleh hikmat kebijaksanaan dalam permusyawaratan/perwakilan, dan keadilan sosial bagi seluruh rakyat Indonesia, dan tercantum pada alinea ke-4 Preambule (Pembukaan) Undang-Undang Dasar 1945.Meskipun terjadi perubahan kandungan dan urutan lima sila Pancasila yang berlangsung dalam beberapa tahap selama masa perumusan Pancasila pada tahun 1945, tanggal 1 Juni diperingati sebagai hari lahirnya Pancasila.

Ideologi merupakan suatu ide atau gagasan. Kata ideologi sendiri diciptakan oleh Antoine Destutt de Tracy pada akhir abad ke-18untuk mendefinisikan "sains tentang ide". Ideologi dapat dianggap sebagai visi yang komprehensif, sebagai cara memandang segala sesuatu (bandingkan Weltanschauung), secara umum (lihat Ideologi dalam kehidupan sehari hari) dan beberapa arah filosofis (lihat Ideologi politis), atau sekelompok ide yang diajukan oleh kelas yang dominan pada seluruh anggota masyarakat. Tujuan utama di balik ideologi adalah untuk menawarkan perubahan melalui proses pemikiran normatif. Ideologi adalah sistem pemikiran abstrak (tidak hanya sekadar pembentukan ide) yang diterapkan pada masalah publik sehingga membuat konsep ini menjadi inti politik. Secara implisit setiap pemikiran politik mengikuti sebuah ideologi walaupun tidak diletakkan sebagai sistem berpikir yang eksplisit. (definisi ideologi Marxisme).

\section{B.Pengertian Pancasila sebagai Ideologi}

Pancasila sebagai ideologi berarti Pancasila merupakan landasan/ide/gagasan yang fundamental dalam proses penyelenggaraan tata pemerintahan suatu negara, mengatur bagaimana suatu sistem itu dijalankan.visi atau arah dari kehidupan berbangsa dan bernegara di Indonesia ialah terwujudnya kehidupan yang menjunjung tinggi ketuhanan, nilai kemanusiaan, persatuan , kerakyatan serta nilai keadilan. visi atau arah dari kehidupan berbangsa dan bernegara di Indonesia ialah terwujudnya kehidupan yang menjunjung tinggi ketuhanan, nilai kemanusiaan, persatuan , kerakyatan serta nilai keadilan. seluruh warga negara Indonesia menjadikan pancasila sebagai dasar sistem kenegaraan. seluruh warga negara Indonesia menjadikan pancasila sebagai dasar sistem kenegaraan. 


\section{C.Hubungan Pancasila sebagai Ideologi}

.Hubungan pancasila sebagai ideologi bangsa Indonesia adalah bahwa nilai-nilai yang terkandung dalam ideologi Pancasila itu menjadi cita-cita normatif bagi penyelenggaraan bernegara. Dengan kata lain, visi atau arah dari penyelenggaraan kehidupan berbangsa dan bernegara Indonesia adalah terwujudnya kehidupan yang ber-Ketuhanan, yang ber-Kemanusiaan, yang ber-Persatuan, yang ber-Kerakyatan, dan yang ber-Keadilan.

\section{D.Makna Pancasila sebagai Ideologi}

\section{Sebagai cita-cita negara}

Ideologi Pancasila sebagai cita - cita negara berarti bahwa nilai - nilai dalam Pancasila diimplementasikan sebagai tujuan atau cita - cita dari penyelenggaraan pemerintahan negara. Secara luas dapat diartikan bahwa nilai - nilai yang terkandung dalam ideologi Pancasila menjadi visi atau arah dari penyelenggaraan kehidupan berbangsa dan bernegara. Visi atau arah yang dimaksud adalah terwujudnya kehidupan yang berdasar Ketuhanan Yang Maha Esa, berperi kemanusiaan, menjunjung tinggi persatuan, pro rakyat, serta adil dan makmur.

Dengan begitu, sudah sewajarnya apabila Pancasila diamalkan dalam seluruh aspek kehidupan. Akan tetapi, contoh yang paling menggambarkan makna Pancasila sebagai ideologi negara adalah dengan mengamalkan nilai Pancasila di bidang politik. Contoh penerapan nilai-nilai pancasila dalam bidang politik ada banyak sekali bentuknya. Sebagai contoh, pemilihan umum yang dilakukan secara langsung, sebagai perwujudan dari sila ke-empat.Dan juga, penetapan kebijakan - kebijakan yang lebih mementingkan kepentingan rakyat dari pada kepentingan pribadi atau golongan. Hal itu sesuai dengan Pancasila sila kelima.

\section{Sebagai nilai integratif bangsa dan negara}

Pancasila sebagai ideologi negara yang diwujudkan dalam nilai integratif bangsa dan negara membuat Pancasila menjadi sarana untuk menyatukan perbedaan bangsa Indonesia. 
Disitulah makna dari Pancasila sebagai ideologi negara memegang peran yang penting untuk persatuan dan kesatuan. Sebagai wujud nilai bersama yang menjadi pemecah konflik atau penyetara kesenjangan.

\section{E.Pandangan para ahli mengenai makna dari pancasila sebagai ideologi}

Beberapa negarawan juga mengungkapkan makna Pancasila sebagai ideologi negara menurut pandangan mereka.

1.Seperti yang disampaikan oleh mantan Presiden pertama Indonesia, Soekarno, bahwa Pancasila adalah asas bersama yang mambu membuat semua kelompok masyarakat di Indonesia ini bersatu dan menerima asas tersebut.

2.Selain itu, Adnan Buyung Nasution pada tahun 1995 ,mengemukakan bahwa telah terjadi perubahan fungsi asli Pancasila. Walaupun mendapat julukan sebagai filsafat atau buah piker yang mendalam, Pancasila sebenarnya dimaksudkan sebagai sarana demokrasi bagi seluruh warga negara Indonesia. Dalam perkembangannya, Pancasila menjadi ideologi yang unik hanya dimiliki oleh Indonesia, dan berbeda dari ideologi yang lainnya.

3.Negarawan Notonegoro mengungkapkan Pancasila sebagai filsafat. Pancasila adalah ideologi yang kemperhensif, mencapuk semua aspek. Hal tersebut menggambarkan bahwa Pancasila itu bersifat massif dan bisa diinterpretasikan dalam berbagai bentuk. Di masa pemerintahan orde baru, bahkan Pancasila menjadi monopoli politik.

\section{F.Fungsi Pancasila sebagai Ideologi}

1.mempersatukan bangsa, memelihara dan mengukuhkan persatuan dan kesatuan itu. Fungsi ini sangatlah penting bagi bangsa Indonesia karena sebagai masyarakat majemuk sering kali terancam perpecahan.

2.membimbing dan mengarahkan bangsa menuju tujuannya. Pancasila memberi gambaran cita-cita bangsa Indonesia sekaligus menjadi sumber motivasi dan tekad perjuangan mencapai cita-cita, menggerakkan bangsa melaksanakan pembangunan nasional sebagai pengamalan Pancasila.

3..memberikan tekad untuk memelihara dan mengembangkan identitas bangsa. Pancasila memberi gambaran identitas bangsa Indonesia, sekaligus memberi dorongan bagi nation and character building berdasarkan Pancasila.

4..menyoroti kenyataan yang ada dan mengkritisi upaya perwujudan cita-cita yang terkandung dalam Pancasila. Pancasila menjadi ukuran untuk melakukan kritik mengenai keadaan Bangsa dan Negara. 


\section{G.Nilai Pancasila sebagai Ideologi}

1. Nilai Dasar Artinya sila-sila Pancasila bersifat universal sehingga didalamnya terkandung cita-cita, tujuan serta nilai-nilai yang baik dan benar. sebuah nilai yang mendasar yang relatif tetap dan tidak berubah dan ini terdapat dalam isi kelima sila dalam Pancasila.

2. Nilai Instrumental Artinya Pancasila dapat dijabarkan lebih lanjut secara kreatif dan dinamis sehingga dapat diterapkan dalam kehidupan sehari-hari dengan catatan, nilainilai penjabarannya tidak bertentangan dengan nilai-nilai dasar Pancasila.

3. Nilai Praktis Artinya Pancasila dapat diterapkan secara riil dalam kehidupan seharihari.perwujudan nilai instrumental dalam bentuk nyata di dalam kehidupan bermasyarakat, berbangsa, maupun bernegara. Dalam perwujudannya nilai praktis bersifat abstrak, misalnya saling menghormati, bekerjasama, dan kerukunan antar sesama.

\section{H.Perbandingan Ideologi Pancasila dengan Ideologi}

\section{Ideologi Komunisme}

Ideologi komunis ini pertama kali diterbitkan pada 18 Februari 1848 berasal dari Manifest der Kommunistischen Manifest der Kommunistischen. Pada saat itupaham ini menjadi salah satu gerakan yang paling berpengaruh dalam dunia .

Pada abad 19 komunisme adalah sebuah paham atau ideologi yang menjadi bahan pembenaran mengenai paham kapitalisme, di masa itu paham ini lebih mengedepankan ekonomi hal itu menjadikan petani atau buruh menjadi bagian dari produksi . Di masa selanjutnya muncul beberapa faksi internal di paham komunis ini, karena adanya perbedaaan teori dan cara perjuangan dalam pencapaian tujuan yaitu masyarakat sosialis untuk berubah menjdai masyarakat yang disebut masyarakat utopia yang didebatkan oleh penganut komunis teori dan komunis revulusioner.

Komunis sebagai paham anti kapitalisme menjadi paham yang sangat menentang akumulasi modal pada individu. Paham ini mempunyai prinsip bahwa semua dipreorientasikan sebagai milik rakyat maka dari itu paham ini beranggapan bahwa semua alat-alat produksi harus dikuasai oleh negara demi kemakmuran rakyat secara merata. Dalam paham ini sistem demokrasi keterwakilan yang dilakukan oleh para petinggi kelompok komunis ini dan membatasi demokrasi pada rakyat yang bukan penganut paham komunis karena dalam komunis tidak ada hak perorangan seperti halnya paham liberalis. Pada dasarnya paham ini tidak berdasarkan kepercayaan mitos, takhayul, dan agama.

Di Indonesia sendiri paham komunis ini berhubungan orang-orang yang pernah begelut dengan politik dari Belanda. Beberapa diantaranya adalah Sneevliet, Bregsma dan Tan Malaka. Gerakan ini berawal dari Surabaya yakni pada saat ada musyawarah interb para pekerja buruh kereta api Surabaya yang biasa disebut dengan VSTP. 
Pada awalnya anggora VTSP ini berasal dari orang-orang Eropa dan indo Eropa, namun setelah sekian lama kaum pribumi juga tak sedikit yang menjadi anggota paham komunis ini. Semaoen adalah salah satu anggota yang dikenal sampai sekarang, dia juga menjadi ketua SI Semarang pada saat itu.

Semarang juga salah satu kota yang menjadi daerah aktif paham komunis yang diketuai oleh semaoen sehingga mempunyai julukan sebagai "kota merah" setelah menjadi basis PKI di era itu. Di era itu kaum pribumi yang beraliran kiri dan ISDV masuk ke dalam Sarekat Islam dan menjadikan komunis sebagai salah satu cabangnya dan diberi julukan sebagai "Si Merah". Hal ini menjadikan ISDV menjadi salah satu penanggung jawab atas adanya pemogokan buruh di daerah jawa.

Asal mula kehancuran PKI karena adanya Persetujuan Prambanan yang memutuskan adanya pemberontakan secara besar-besaran di seluruh Hindia-Belanda. Pemberontakan terjadi pada Tahun 1926-1927 yang berakhir denga kekalahan PKI. Para tokoh PKI menyalahkan Tan malaka atas kekalahan itu sebab pada saat pemberontakan besar-besaran dilakukan, Tan Malaka menjadi orang yang tidak setuju akan adanya paham komunis dan mencoba mengehentikan pemberontokan dan mempengaruhi cabang-cabang PKI.

Keunggulan ideologi komunis

1. Paham komunis ini mempunyai suatu kebijakan bahwa perokonomian di berikan seutuhnya ke tangan pemerintah. seperti perencanaan, pelaksaan, pengawasan maka pemerintah lebih mudah mengendalikan inflansi, tingkat penganguran dan keburukan perokonomian lainnya.

2. Pemerintah yang menjadi penentu perencaan kegiatan produsi sehingga pasar dalam negeri dalam berjalan dengan lancar karena pengendali hanya satu sehingga tidak ada perbedaan pendapat saat mengatur perencanaan kegiatan.

3. Sudah melalakukan distribusi pendapatan.

4. Jarang terjadi krisis ekonomi karena semua kegiatan diatur langsung oleh pemerintah yang mempunyai pandangan ekonomi lebih luas.

Kekurangan ideologi komunis.

1. Pers menjadi alat propaganda oleh pemerintah untuk menyebarkan nilainilai komunis kepada masyarakat.

2. Menonaktifkan intensiv individu karena semua kegiatan diatur oleh pusat.

3. Sering terjadi monopoli yang merugikan masyrakat.

4. Dan masyarakat tidak mempunyaSi kebebasan dalm memiliki sumber daya.

\section{Ideologi Liberalisme}

Munculnya ideologi liberalisme dilatarbelakangi oleh situasi di Eropa sebelum abad ke-18 yang diwarnai oleh perang agama, feodalisme, dominasi kelompok aristokrasi, dan bentuk pemerintahan yang bercorak monarki absolut. Dalam situasi demikian, ide-ide liberal yang mencerminkan aspirasi kelompok industrialis dan pedagang mulai diterima. 
Selanjutnya, dengan dukungan pemikir-pemikir liberal klasik seperti John Locke, J.S. Mill, Herbert Spencer, Adam Smith, dan David Hume, ide-ide liberal tersebut mulai terwujud baik dalam pemikiran ekonomi, politik maupun sosial, hingga akhirnya perkembangan liberalisme sebagai ideologi politik, semakin mantap seiring dengan terjadinya Revolusi Inggris (1688), Revolusi Amerika (1776) dan Revolusi Prancis(1789).

Ketiga Revolusi tersebut mengukuhkan dua prinsip hukum yang mendasari politik liberal, yaitu (1) pernyataan tentang hak asasi manusia (HAM), dan (2) adanya konstitusi yang menetapkan tatanan politik. Di tingkat praksis, kedua prinsip tersebut menjiwai pedoman-pedoman dalam kehidupan bernegara. Pedoman-pedoman tersebut antara lain ialah (1) adanya hukum yang tidak memihak dan berlaku umum (tidak ada keistimewaan bagi kelompok ningrat, agamawan, atau golongan terpandang lainnya) dan (2) hukum dibuat untuk menjamin sebesar mungkin hak yang sama bagi tiap individu agar mereka dapat mengejar tujuan hidupnya (Eatwell dan Wright (ed.), 2001).

Terdapat beberapa prinsip dasar yang melandasi liberalisme, yaitu individualisme, kebebasan, keadilan dan kesetaraan, serta utilitarianisme:

1. Individualisme

Individualisme merupakan inti pemikiran liberal yang menjiwai seluruh basis moral, ekonomi, politik, dan budaya. Individualisme sendiri dapat diartikansebagai pemikiran yang menjunjung keberadaan individu, dan masyarakat hanya dipandang sebagai sekumpulan individu semata. Individu memiliki otonomi dan merupakan sumber seluruh nilai. Individu juga dianggap sebagai hakim yang terbaik bagi dirinya serta dapat bertanggung jawab kepada dirinya sendiri. Bertitik tolak dari pandangan ini, kelompok liberal beranggapan bahwa negara tidak berhak mengintervensi kehidupan warga negara.

2. Kebebasan

Kebebasan dalam liberalisme dipandang sebagai "hak" yang dimiliki tiap orang. Hak ini yang memungkinkan tiap individu mendapat kesempatan yang sama untuk mengejar kepentingannya. Dari perspektif liberalisme, kebebasan tidak hanya dipandang sebagaihak melainkan juga sebagai kondisi yang memungkinkan tiap-tiap individu dapat mengembangkan bakat dan ketrampilannya. Dalam hal ini kebebasan yang dimaksud adalah kebebasan dalam hal positif.

3. Keadilan dan kesetaraan

Nilai keadilan yang dijunjung kaum liberal dilandasi oleh komitmen terhadap nilai kesetaraan. Tekanan liberalisme di sini adalah keyakinan bahwa secara universal manusia memiliki hak yang sama, dan secara moral kedudukan manusia adalah setara. Dengan demikian, tiap-tiap individu memiliki hak dan kesempatan yang setara untuk mengembangkan kemampuan dan keterampilannya.Oleh sebab itu, menurut kaum liberal, kesetaraan kesempatan harus terbuka bagi tiap individu agar mereka dapat menikmati hak-hak dan penghormatan yang sama. Dan kaum liberal tidak melihat bahwa ide kesetaraan kesempatan akan mengarah pada ketidaksetaraan sosial dan ekonomi. 


\section{Utilitarianisme}

Prinsip utilitas atau manfaat adalah prinsip yang memungkinkan tiap-tiap individu dapat mengkalkulasi apa yang secara moral baik dengan menjumlahkan keuntungan/kenikmatan yang diperoleh dari setiap aspek tindakan yang dipilih. Di tingkat masyarakat pun, prinsip ini dapat dijadikan pedoman untuk pengambilan keputusan yang menguntungkan masyarakat banyak, yang kemudian dikenal sebagai prinsip "the greatest happiness for the greatest number". Dengan demikian, pilihan tindakan individu selalu didasarkan pada perhitungan jumlah keuntungan yang diperoleh ketimbang kerugiannya. Inilah yang dimaksud dengan prinsip utilitas.

Liberalisme dapat dikatakan sebagai ideologi yang begitu menyatu dalam kehidupan masyarakat Barat, namun tidak lepas dari kritik. Padaabad ke-20, bahkan hingga awal abad ke-21 ini, telah banyak pihak yang mulai mempertanyakan prinsipprinsip dasar liberalisme klasik seiring dengan munculnya dampak industri modern. Hal ini disebabkan kelompok liberal terlalu membesar-besarkan nilai kebebasan dan kesetaraan kesempatan bagi individu, sementara dalam realitas, kesempatan dalam bentuk peluang kerja tidak tersedia secara merata dimasyarakat. Sebagai upaya untuk menanggapi tantangan terhadap liberalisme klasik tersebut, dikembangkanlah liberalisme modern yang lebih sesuai dengan kondisi masyarakat modern oleh tokohtokoh seperti T.H. Green, L.T. Hobhouse, J.M. Keynes, John Rawls, dan Robert Nozick.

\section{Kelemahan dan Kelebihan}

a. Kelebihan ideologi Liberalisme

1. Menumbuhkan inisiatif dan kreasi masyarakat dalam mengatur kegiatan ekonomi. Masyarakat tidak perlu menunggu komando dari pemerintah.

2. Setiap individu bebas untuk memiliki sumber-sumber daya produksi. Hal ini mendorong partisipasi aktif dari masyarakat dalam perekonomian.

3. Timbul persaingan untuk maju karena kegiatan ekonomi sepenuhnya diserahkan kepada masyarakat.

4. Menghasilkan barang-barang bermutu tinggi, karena barang yang kurang bermutu tidak akan laku di pasar.

5. Kontrol sosial dalam sistem pers berlaku secara bebas. Berita-berita ataupun ulasan yang dibuat dalam media massa dapat mengandung kritik-kritik tajam, baik ditujukan kepada perseorangan lembaga atau pemerintah.

6. Masyarakat dapat memilih partai politik tanpa ada gangguan dari siapapun. 
b. Kelemahan Ideologi Liberalisme

1. Sulit melakukan pemerataan pendapatan. Hal ini dikarenakan persaingan bersifat bebas, dimana pendapatan jatuh kepada pemilik modal ataupun majikan. Sedangkan golongan pekerja hanya menerima sebagiankecil dari pendapatan.

2. Pemilik sumber daya produksi mengeksploitasi golongan pekerja, sehingga yang kaya semakin kaya, yang miskin semakin miskin.

3. Sering munculnya monopoli yang merugikan masyarakat.

4. Sering terjadi gejolak dalam perekonomian karena kesalahan alokasi budaya oleh individu yang sering terjadi.

5. Karena penyelenggaraan pers dilakukan oleh pihak swasta, pemerintah sulit untuk mengadakan dan memberikan kontrol. Sehingga pers sebagai media komunikasi dan media massa sangat efektif menciptakan gambaran dimasyarakat sesuai misi kepentingan mereka.

\section{Ideologi Pancasila}

Pencasila sebagai dasar filsafat serta ideologi bangsa dan negara Indonesia, bukan terbentuk secara mendadak serta bukan hanya diciptakan oleh seseorang sebagaimana yang terjadi pada ideologi-ideologi lain di dunia, namun terbentuknya Pancasila melalui proses yang cukup panjang dalam sejarah bangsa Indonesia.

Secara kausalitas Pancasila sebelum disahkan menjadi dasar filsafat negara nilai-nilainya telah ada dan berasal dari bangsa Indonesia sendiri yang berupa nilai-nilai adat istiadat, kebudayaan dan nilai-nilai religius. Kemudian para pendiri negara Indonesia mengangkat nilai-nilai tersebut dan dirumuskan secara musyawarah mufakat berdasarkan moral yang luhur, antara lain dalam sidang-sidang BPUPKI pertama, sidang Panitia Sembilan yang kemudian menghasilkan piagam Jakarta yang memuat Pancasila yang pertama kali, kemudian dibahas lagi dalam sidang BPUPKI yang kedua. Setelah kemerdekaan Indonesia sebelum sidang resmi PPKI Pancasila sebagai calon dasar filsafat negara dibahas serta disempurnakan kembali dan akhirnya pada tanggal 18 Agustus 1945 disahkan oleh PPKI sebagai filsafat negara republik Indonesia.

Ditinjau secara kausalitas asal mula Pancasila dibedakan atas dua macam yaitu: asal mula langsung dan asal mula tidak langsung. Asal mula langsung tentang pancasila adalah asal mula terjadinya pancasila sebagai dasar filsafat negara yaitu asal mula sesudah dan menjelang proklamasi Kemerdekaan yaitu sejak dirumuskan oleh para pendiri negara sejak sidang BPUPKI pertama, Panitia Sembilan, sidang BPUPKI kedua serta sidang PPKI sampai pengesahannya. Asal mula tidak langsung tentang Pancasila adalah asal mula sebelum proklamasi kemerdekaan, yaitu asal mula adanya nilai-nilai pancasila yang terdapat dalam adat istiadat, dalam kebudayaan serta dalam nilai-nilai agama bangsa Indonesia.

Dengan demikian Pancasila pada hakikatnya adalah sebagai pandangan hidup bangsa Indonesia, yang jauh sebelum bangsa Indonesia membentuk negara, nilai-nilai tersebut telah tercermin dan teramalkan dalam kehidupan sehari-hari. 
Fungsi pokok Pancasila, yaitu:

Pancasila sebagai dasar negara

1. Sebagai negara. Pancasila berkedudukan sebagai norma dasar atau norma fundamental (fundamental norm). Dengan demikian, Pancasila menempati norma hukum tertinggi dalam ideologi Indonesia.

2. Sebagai sumber dari segala sumber hukum. Pancasila merupakan kaidah negara yang fundamental, artinya kedudukannya paling tinggi dalam penyusunan aturanaturan di Indonesia.

3. Sebagai pandangan hidup. Nilai Pancasila merupakan pedoman dan pegangan dalam pembangunan bangsa dan negara.

4. Sebagai jiwa dan kepribadian bangsa Indonesia. Nilai Pancasila mencerminkan kepribadian bangsa sebab nilai dasarnya merupakan kristalisasi nilai budaya bangsa Indonesia.

5. Sebagai perjanjian luhur bangsa Indonesia. Pancasila lahir dari hasil musyawarah para pendiri bangsa dan negara (founding fathers).

Pencasila sebagai ideologi negara.

Ideologi dapat dibedakan menjadi dua pengertian, yaitu ideologi dalam arti luas dan ideologi dalam arti sempit. Dalam arti luas, ideologi menunjuk sebagai pedoman hidup disemua segi kehidupan, baik pribadi maupun umum. Sedangkan dalam arti sempit, menunjuk sebagai pedoman hidup dalam bidang tertentu, misalnya sebagai ideologi negara. Ideologi negara merupakan ideologi mayoritas warga negara tentang nilai-nilai dasar negara yang ingin diwujudkan melalui kehidupan negara itu. Pancasila adalah ideologi negara, yaitu gagasan fundamental mengenai bagaimana hidup bernegara. Sebagai ideologi bangsa Indonesia, Pancasila sebagai ikatan budaya (cultural bond) yang berkembang secara alami dalam kehidupan masyarakat Indonesia, bukan secara paksaan.

Fungsi Pancasila sebagai ideologi negara, yaitu:

1. Memperkokoh persatuan bangsa karena bangsa Indonesia adalah bangsa yang majemuk.

2. Mengarahkan bangsa Indonesia menuju tujuannya dan menggerakan serta membimbing bangsa Indonesia dalam melaksanakan pembangunan.

3. Memelihara dan mengembangkan identitas bangsa dan sebagai dorongan dalam pembentukan karakter bangsa berdasarkan Pancasila.

4. Menjadi standar nilai dalam melakukan kritik mengenai keadaan bangsa dan negara. 
Pancasila sebagai sebuah ideologi memiliki tiga dimensi, yaitu:

1. Dimensi Realita, artinya nilai-nilai dasar yang terkandungdalam ideologi itu secara riil berakar dan hidup dalam masyarakatatau bangsanya, yaitu mencerminkan kenyataan hidup yang ada di dalam masyarakat di mana ideologi itu muncul untuk pertama kalinya.

2. Dimensi Idealisme, artinya kualitas ideologi yang terkandung dalam nilai dasar itu mampu memberikan harapan kepada berbagai kelompok dan masyarakat tentang masa depan yang lebih baik.

3. Dimensi Fleksibilitas, atau dimensi pengembangan artinya kemampuan ideologi dalam mempengaruhi dan menyesuaikan diri dengan perkembangan masyarakatnya.

Dengan memandang pengertian ideologi sebagai sebuah ide atau gagasan, Franz Magnis-Suseno menyatakan bahwa ideologi tertutup dan ideologi terbuka. Ideologi tertutup adalah ideologi yang nilainya bersifat mutlak. Ideologi tertutup bersifat dogmatis dan apriori. Dogmatis berarti memercayai suatu keadaan tanpa data yang valid, sedangkan apriori berarti berprasangka terlebih dahulu akan suatu keadaan. Ideologi tertutup memiliki ciri-ciri sebagai berikut.

1. Cita-cita sebuah kelompok, bukan cita-cita yang hidup di masyarakat.

2. Bersifat totaliter, menguasai semua bidang kehidupan masyarakat.

3. Tidak ada keanekaragaman, baik pandangan maupun budaya.

4. Rakyat dituntut memiliki kesetiaan total pada ideologi mutlak, konkret, nyata, keras, dan total.

Ideologi terbuka adalah ideologi yang pemikirannya terbuka. Ciri-ciri ideologi ini antara lain:

1. Merupakan kekayaan rohani, budaya, dan masyarakat.

2. Tidak diciptakan oleh negara, tetapi digali dari budaya masyarakat.

3. Isinya tidak instan atau operasional sehingga tiap generasi boleh menafsirkannya.

4. Menginspirasi masyarakat untuk bertanggung jawab.

Perbedaan dari kedua ideologi ini adalah ideologi terbuka bersifat inklusif, tidak totaliter, dan tidak dapat dipakai melegitimasi kekuasaan sekelompok orang, artinya bahwa sistem ini bersifat demokratis dan terbuka. Sedangkan ideologi tertutup bersifat otoriter (negara berlaku sebagai penguasa) dan totaliter. 
Berdasarkan ciri-ciri yang sudah disebutkan sebelumnya, Pancasila memenuhi syarat sebagai ideologi terbuka.

1. Pancasila adalah pandangan hidup yang berakar pada kesadaran masyarakat Indonesia.

2. Isi Pancasila tidak langsung operasional, hanya berisi lima dasar, yaitu Ketuhanan, Kemanusiaan, Persatuan,Kerakyatan, dan Keadilan. Karena hanya berisi nilai dasar, maka perlu adanya penafsiran.

3. Pancasila menghargai kebebasan. Hal ini tercermin dalam makna sila kedua yang tidak saja mengakui kebebasan dan kesedarajatan manusia Indonesia, tetapi semua bangsa di dunia.

4. Pancasila adalah ideologi politik, pedoman hidup masyarakat, bangsa, dan negara.

5. Pancasila menghargai pluralitas, seperti yang tercermin dalam sila pertama. Sila ini mencerminkan semua agama yang ada di Indonesia.

Sebagai ideologi terbuka, Pancasila harus mampu menyesuaikan diri dengan zaman. Hal ini bukan berarti nilai dari Pancasila dapat diganti dengan nilai dasar lain yang dapat menghilangkan jati diri bangsa Indonesia. Makna Pancasila sebagai ideologi terbuka adalah nilai-nilai dasar Pancasila dapat dikembangkan sesuai dengan dinamika kehidupan bangsa Indonesia dan tuntutan perkembangan zaman dengan memperhaitkan tingkat kebutuhan dan perkembangan masyarakat Indonesia, serta tidak keluar dari eksistensi dan jati diri bangsa Indonesia. Ideologi Pancasila menghendaki agar bangsa Indonesia tetap bertahan dalam jiwa dan budaya bangsa Indonesia dan dalam ikatan NKRI.

Menurut moerdiono, faktor-faktor yang mendorong pemikiran Pancasila sebagai ideologi terbuka adalah:

1. Perkembangan dinamika masyarakat Indonesia yang cepat sehingga tidak semua persoalan hidup dapat ditemukan jawabannya secara ideologis;

2. Runtuhnya ideologi tertutup, seperti Marxisme-Leninisme/komunisme;

3. Pengalaman sejarah politik Indonesia dengan pengaruh komunisme; dan

4. Tekad bangsa Indonesia untuk menjadikan Pancasila sebagai satu-satunya asas dalam kehidupan bermasyarakat, berbangsa, dan bernegara. (Pancasila sebagai satu-satunya asa telah dicabut oleh MPR pada tahun 1999).

\section{Keunggulan dan Kelemahan Ideologi Pancasila}

Keunggulan

- Memiliki sikap-sikap positif yang dimiliki ideology-ideologi lain yang ada di dunia

- Membela rakyat

- $\quad$ Peran serta negara tidak membuat rakyat menderita (seharusnya)

- $\quad$ Seluruh komponen masyarakat saling memiliki keterikatan

- Bersifat terbuka

- $\quad$ Memberi kebebasan kepada rakyat (dalam berpolitik dan beragama)

- Menjunjung tinggi hak asasi manusia tanpa menghilangkan hak orang lain, dll. 
Kelemahan

Terlalu ditinggi-tinggikan (berlebihan)

Kelemahan Pancasila dibandingkan ideology-ideologi lain sangatlah sulit untuk dicari. Karena Pancasila sendiri mengambil segala hal-hal positif yang ada dalam setiap ideology yang ada. Untuk bangsa Indonesia Pancasila memang sudah tepat apabila dijadikan sebagai ideology bangsa, hanya saja cara pengamalan bangsa kita saat ini terhadap Pancasila sudah salah kaprah. Segala sesuatu yang menjadi makna atau nilai Pancasila tersebut seakan-akan sudah tidak ada lagi. Dan pratek untuk mengamalkan nilai-nilai Pancasila lama-kelamaan mulai memudar.

\section{Perbedaan Ideologi Pancasila dengan Liberalisme, dan Komunisme}

1. Ideologi Pancasila dengan Liberalisme Pancasila:

a) Kepemilikan individu dibatasi pada kepentingan yang tidak menjadi hajat hidup orang banyak.

b) Bercampurnya aspek kepemerintahan dengan agama.

c) Masih adanya pembatasan oleh pemerintah dan agama. Liberalisme:

a) Kepemilikan individu tidak dibatasi sama sekali.

b) Aspek pemerintahan dan keagamaan dilarang untuk dicampur adukkan.

c) Penolakan terhadap pembatasan oleh pemerintah dan agama.

Persamaan:

Sama-sama menganut sistem demokrasi, dimana semua orang berhak menyuarakan pendapatnya.

2. Ideologi Pancasila dengan Komunisme

Pancasila:

a) Hak milik pribadi dan negara dipisahkan dengan jelas dan diperbolehkan sesuai peraturan.

b) Menimbulkan adanya kelas dalam masyarakatdengan penanganan masing-masing.

c) Pemerintah yang demokratis.

Komunisme:

a) Penghapusan seluruh hak milik pribadi dan negara menjadi hak milik besama.

b) Terciptanya negara tanpa kelas.

c) Pemerintahan cenderung otoriter agar rakyat dapat diatur sepenuhnya.

\section{I.Faktor-faktor yang mendasari Pancasila dipilih sebagai Ideologi}

1.Pancasila merupakan Ide ide para pahlawan bangsa

2.Pancasila merupakan sumber dari segala sumber hukum

3.Pancasila merupakan aturan paling umum pada bangsa Indonesia 


\title{
BAB III
}

\section{PENUTUP}

\begin{abstract}
A.Kesimpulan
Pancasila sebagai dasar negara dan pandangan hidup sekaligus juga merupakan ideologi negara. Sebagai ideologi negara berarti pancasila merupakan gagasan dasar yang berkenaan dengan kehidupan negara.Pancasila bukan hanya suatu yang bersifat statis melandasi berdirinya negara Indonesia akan tetapi pancasila membawakan gambaran mengenai wujud masyarakat tertentu yang diinginkan serta prinsip-prinsip dasar yang harus diperjuangkan untuk mewujudkannya.

Pancasila membawakan nilai-nilai tertentu yang digali dari realitas sodio budaya bangsa Indonesia. Ideologi membawakan kekhasan tertentu yang membedakannya dengan ideologi lainnya. Kehasan itu adalah keyakinan akan adanya Tuhan Yang Maha Esa,yang membawa konsekuensi keimanan dan ketaqwaan terhadap Tuhan Yang Maha Esa. Keberadaan ideologi Pancasila dilihat dari dimensi realitas membawakan nilai-nilai yang mencerminkan realitas sosiobudaya bangsa Indonesia, dari segi idealitas mamidpu memberikan keyakian akan terwujudnya masyarakat yang dicitacitakan, dan dari dimensi Fleksibilitas, nilai-nilai yang ada didalamnya dapat dijabarkan secara konstektual agar senantiasa dapat menyesuaikan dengan dinamika dan perkembangan masyarakat.
\end{abstract}

\section{B.Saran}

Sebagai rakyat Indonesia kita sebaiknya selalu menjaga ideologi negara kita yaitu Pancasila karena pancasila merupakan gagasan dasar yang berkenaan dengan kehidupan negara. 


\section{HASIL LAPORAN WAWANCARA (DOKUMENTASI)}

\section{PERTANYAAN :}

A.Bagaimana menurut anda sebagai masyarakat mengenai Pancasila sebagai Ideologi?

1. Nama : Runggu Naomi Siregar S.Pd

Profesi : Guru SD

Pendapat : Tujuan kita untuk menerapkan apa itu moral kepada anak-anak kita, yang diterapkan di sekolah dasar, dan sikap untuk menentukan bagaimana karakter mereka di hari esok yang akan mereka lihat cara pandang pancasila. Serta dapat membuat penerus bangsa Indonesia semakin berpikir luas dalam mengembangkan sikap moral di kedepan hari dan mampu menciptakan sikap yang patut dicontoh untuk anak bangsa.

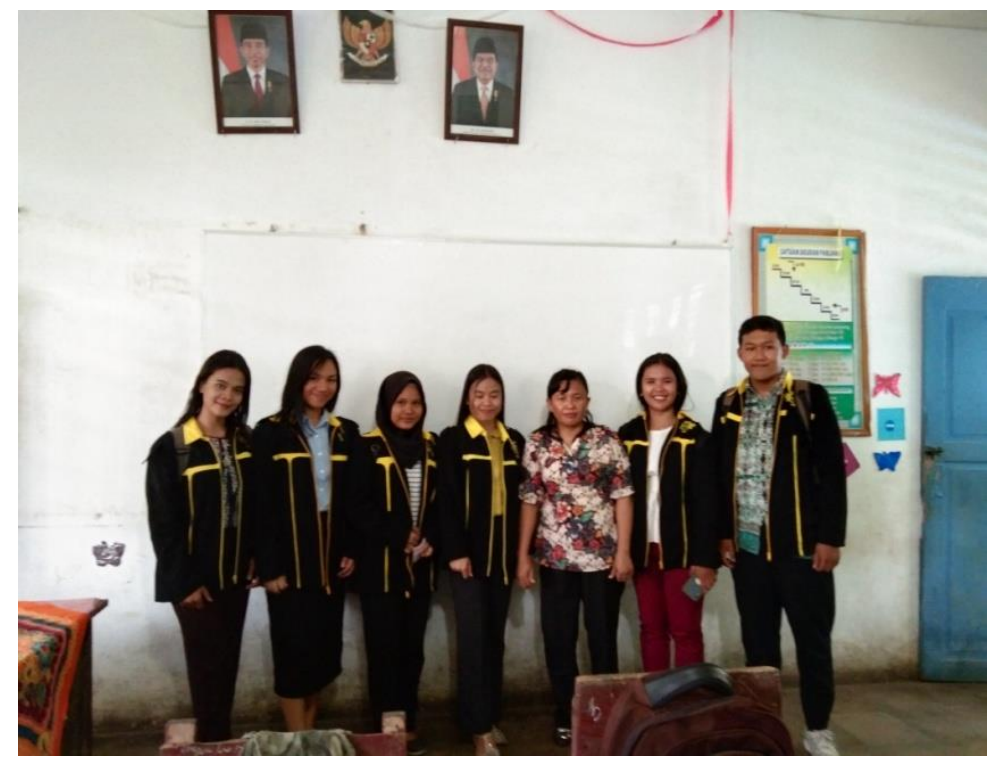

2. Nama : Musim Ketaren

Profesi : Kepala Urusan Pemerintahan Desa Silebo-Lebo

Pendapat : Bagus. Karena pancasila itu dari dulu berlandaskan pancasila, jadi kita tidak harus mengubah isi pancasila. Sebab dalam pancasila yang terdapat 5 sila yang sudah mencakup semua aspirasi masyarakat serta keinginan yang harus di wujudkan oleh suatu pemerintah dalam menggapai apa yang diinginkan suatu masyarakat dalam memenuhi semua hak-hak masyarakat baik dalam martabat nya. 


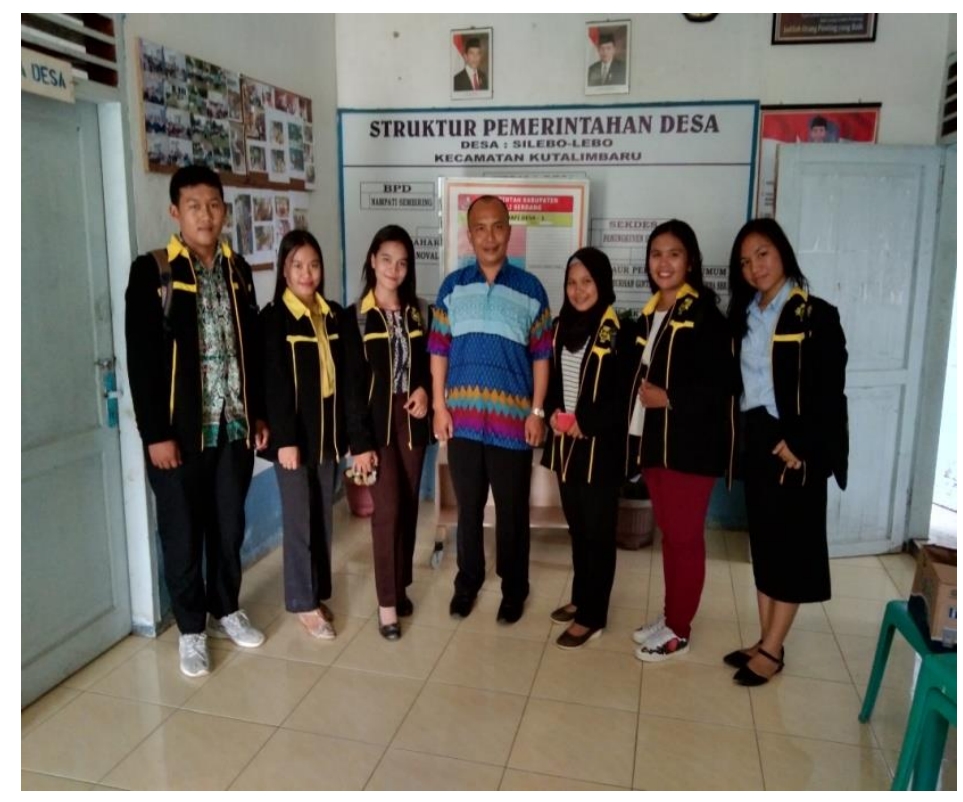

3. Nama : Irawati Br Sitepu Amd.Kep

Profesi : Akper Bina Kasih

Pendapat : Menurut saya pancasila sebagai ideologi itu suatu kumpulan nilainilai dan norma menurut sila-sila pancasila. Menurut sebagai perawat sila kedua, dituntut supaya tidak membeda-bedakan pasien agar pasien dapat merasakan pelayanan yang terbaik oleh para pengurus di RS dan dituntut agar selalu bersikap ramah dan sopan dalam melayani pasien tersebut.

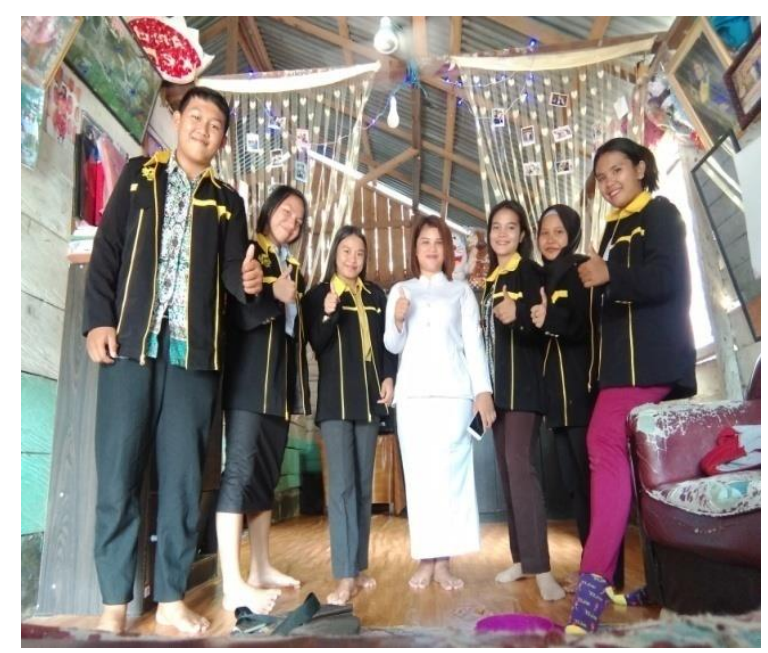




\section{Nama : Pdt. Mirawati Br Tarigan \\ Profesi : Pendeta Silebo-Lebo}

Pendapat : Menurut pandangan Ibu pancasila sebagai ideologi itu kan sebagai identitas berfungsi sebagai cara kita memahami bahwa bangsa Indonesia adalah bangsa yang beragam yang berbeda tetapi memiliki satu tujuan kebangsaan sehingga terciptanya kesatuan tanpa membedakan ras,agama,suku dan etnis bangsa. Yang dimana di dunia memiliki banyak perbedaan tetapi adanya perbedaan kita harus saling menghargai satu dengan yang lainnya.

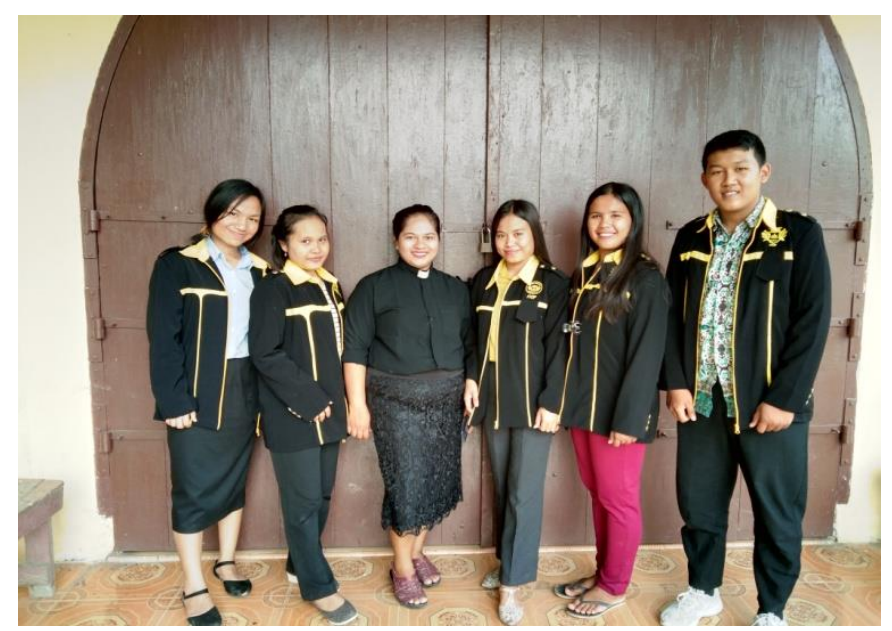


5. Nama : Ramlan Surbakti

Profesi : Masyarakat

Pendapat : Menurut Bapak sila ke-5 tidak pas atau tidak sesuai.Sebab,orang yang kurang mampu tidak pernah mendapatkan keadilan dikarenakan kurang tegasnya suatu pemerintah di Negara dalam keadilan di masyarakat, baik dalam hak manusia di Negara kurang diutamakan.

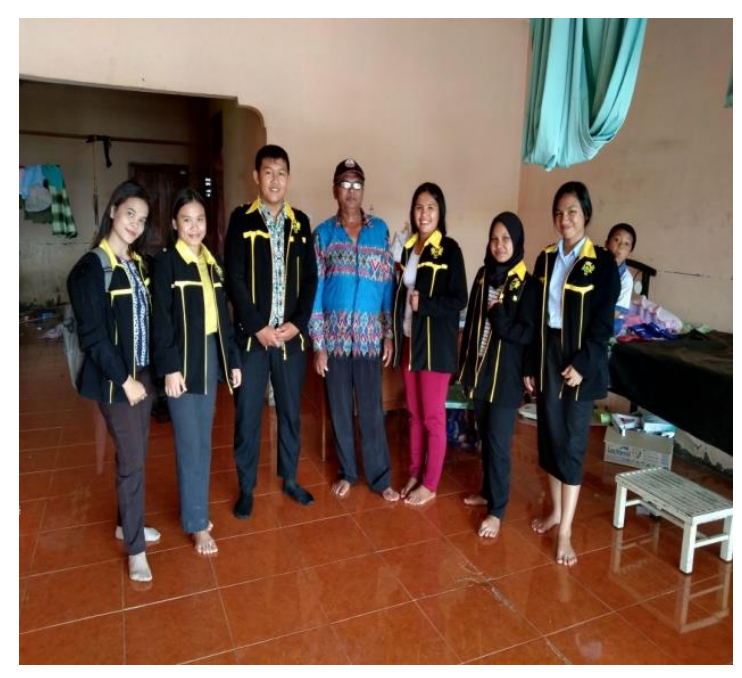

6. Nama : Anggi

Profesi : Polwan

Pendapat : Menurut saya sebagai polwan,ideologi yang diterapkan diindonesia ini terhadap pancasilanya sudah bagus. Dikarenakan pancasila di Negara kita memiliki sila-sila yang sudah tercantum semua aspirasi masyarakat dalam kehidupan sehari-hari dengan mewujudkan hak apa yang harus diterima dan diperoleh oleh suatu masyarakat. 


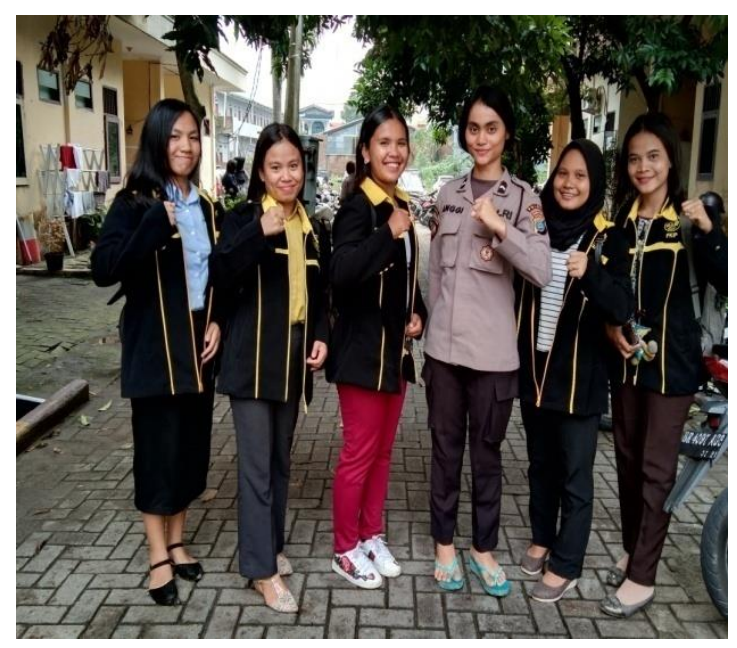

7.Nama $\quad$ : Muflih Fauzi

Profesi :Bripda

Pendapat : Menurut saya pancasila memang ideologi bangsa Indonesia.Jadi pancasila sebagai pemersatu bangsa.Karena pancasila sudah menjadi mendarah daging bangsa Indonesia Indonesia.maka dari itu Harus tetap melestarikan dan menjaga ke sosilidaritasan sesama manusia dan selalu membawa sikap positif yang patut diteladani untuk penerus bangsa di kemudian hari dan menciptakan hubungan yang baik dalam bermasayrakat.

B.Menurut pendapat anda,apakah memilih Pancasila sebagai Ideologi(Pandangan hidup bangsa atau Negara)bagus atau layak diterapkan dimasyarakat?

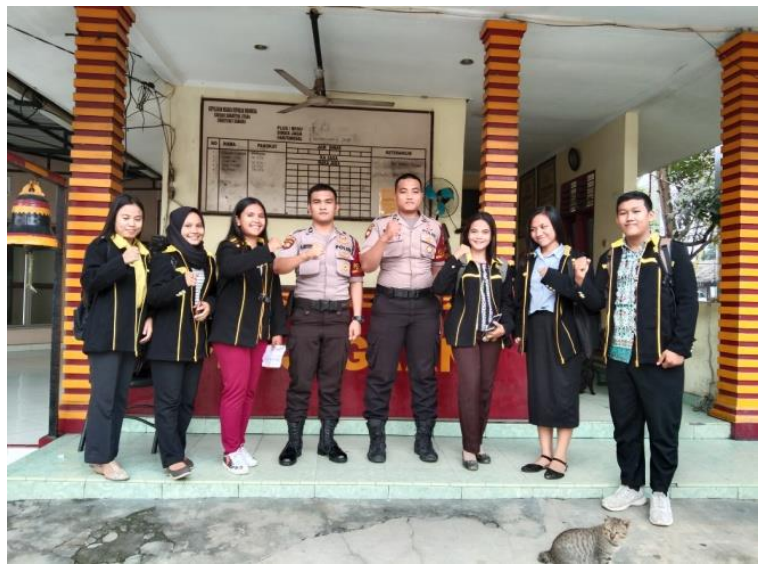




\section{Nama : Helmidawati Sembiring S.pd}

\section{Profesi : Guru SD}

Pendapat : Menurut Ibu sebagai guru pancasila itu bagus. Pancasila itu mengandung banyak nilai-nilai yang harus kita pakai dalam kehidupan sehari-hari dikarenakan banyak pada saat ini masyarakat salah dalam bergaul sehingga dapat merusak hidup anak bangsa, oleh karena itu kita sebagai guru di paksa untuk mampu membuat anak didik kita bersikap moral sehingga dapat menerapkan ke masyrakat lainnya dalam mewujudkan sikap yang terkait dalam pancasila, baik dalam sikap nya terhadap sesama, dan sikap kerohaniannya dalam beragama di mata TUHAN.

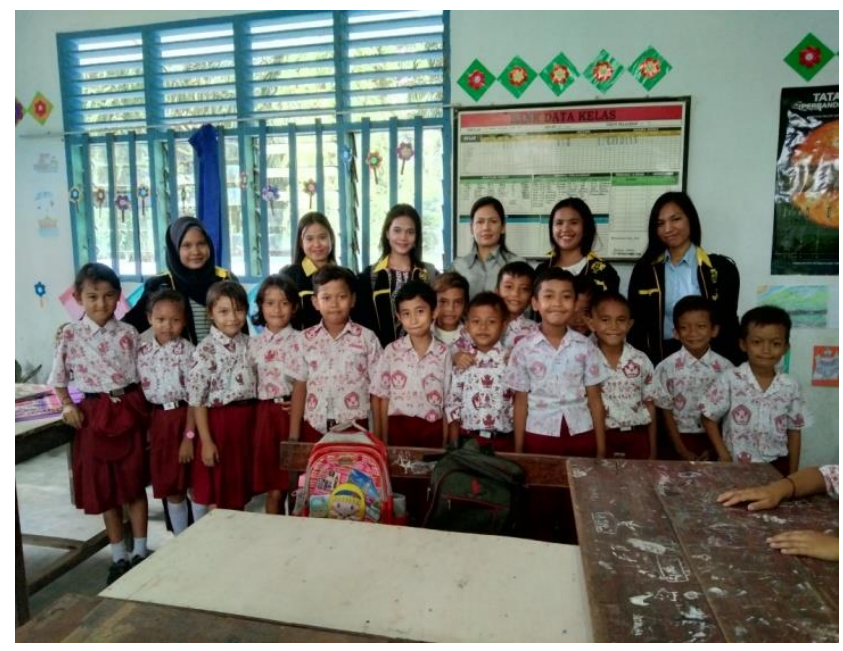




\section{Nama : Neta Tambunan}

\section{Profesi : Polwan}

Pendapat : Menurut saya pancasila yang semua sila sangat bagus diterapkan dimasyarakat seperti ketuhanan yang maha esa karena diindonesia banyak berbagai suku dan bangsa dan adanya sila sila di Negara kita dapat mematuhinya meskipun tidak semua masyarakat di Indonesia melaksanakannya. Dengan menerapkan sila sila itu masyarakat dapat menjadi contoh anak bangsa.

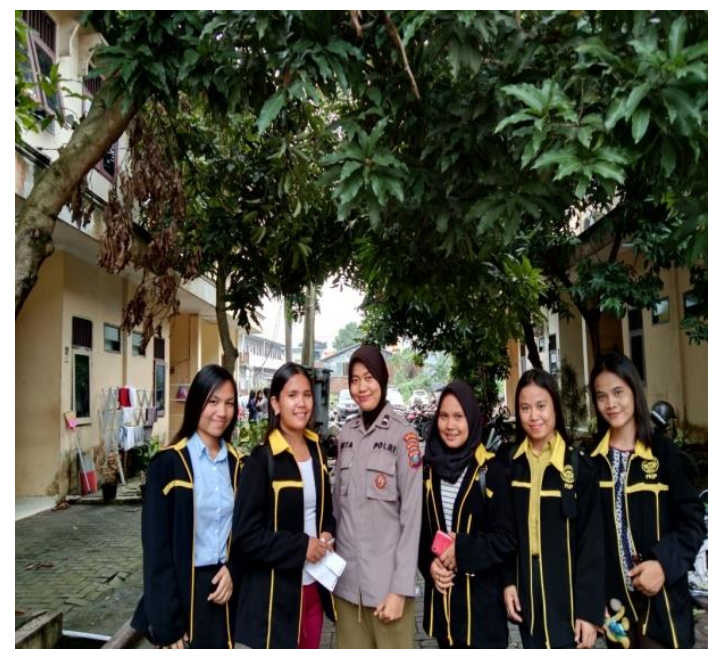


10. Nama : Alek Ritonga

\section{Profesi : Bripda}

Pendapat : Menurut saya pancasila itu sangat cocok diterapkan

dimasyarakat.Musyawarah dan Funding Fader bangsa.Jadi itu tuah pikiran oleh pahlawan pahlawan kita,pancasila itu dapat diterapkan di masyarakat.serta kami sebagai polisi mampu menjaga dan melindungi masyarakat kami dari tindakan yang jahat seperti mencegah pemakaian dan pengedaran narkoba, menghukum para begal, dan tindakan yang dapat membahayakan manusia. Dengan menindaklanjuti pokok permasalahan di setiap kesalahan yang ada.

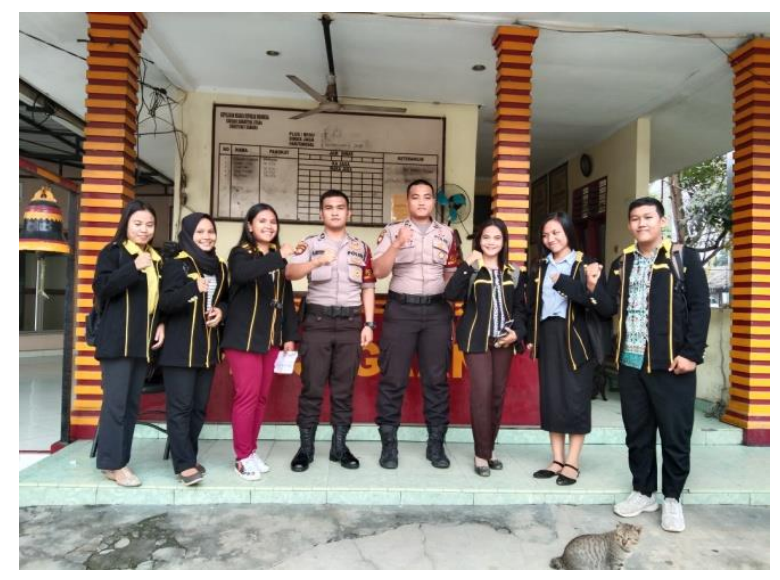




\section{DAFTAR PUSTAKA}

https://id.wikipedia.org/wiki/Pancasila

https://thegorbalsla.com/pengertian-pancasila/

https://www.gurupendidikan.co.id/pancasila-sebagai-dasar-negara/

https://id.wikipedia.org/wiki/ldeologi

Surbakti, K. (2018). UPAYA MENINGKATKAN HASIL BELAJAR PKN SISWA DENGAN MENGGUNAKAN MODEL TALKING STICK MATERI SISTEM PEMERINTAHAN

PUSAT. JURNAL TEMATIK, 8(1), 166-171.

Surbakti, K. (2017). Pengaruh Game Online terhadap Remaja. JURNAL CURERE, 1(1). 